\title{
What Is Wrong with Monetary Sanctions? Directions for Policy, Practice, and Research
}

\author{
BRITTANY FRIEDMAN॰, ALEXES HARRIS, BETH M. HUEBNER(, \\ KARIN D. MARTIN॰, BECKY PETTIT, SARAH K.S. SHANNON®, \\ AND BRYAN L. SYKES (1)
}

\begin{abstract}
Monetary sanctions are an integral and increasingly debated feature of the American criminal legal system. Emerging research, including that featured in this volume, offers important insight into the law governing monetary sanctions, how they are levied, and how their imposition affects inequality. Monetary sanctions are assessed for a wide range of contacts with the criminal legal system ranging from felony convictions to alleged traffic violations with important variability in law and practice across states. These differences allow for the identification of features of law, policy, and practice that differentially shape access to justice and equality before the law. Common practices undermine individuals' rights and fuel inequality in the effects of unpaid monetary sanctions. These observations lead us to offer a number of specific recommendations to improve the administration of justice, mitigate some of the most harmful effects of monetary sanctions, and advance future research.
\end{abstract}

Keywords: monetary sanctions, LFOs, policy, abolition, data, fines and fees

Brittany Friedman is an assistant professor of sociology at the University of Southern California, United States. Alexes Harris is Presidential Term Professor of Sociology at University of Washington, United States. Beth M. Huebner is a professor in the Department of Criminology and Criminal Justice at the University of Missouri-St. Louis, United States. United States. Karin D. Martin is assistant professor at the Daniel J. Evans School of Public Policy and Governance at the University of Washington, United States. Becky Pettit is the Barbara Pierce Bush Regents Professor of Liberal Arts in Sociology at the University of Texas at Austin, United States, where she is also a faculty affiliate of the Population Research Center. Sarah K.S. Shannon is an associate professor of sociology at the University of Georgia, United States. Bryan L. Sykes is an Inclusive Excellence Term Chair Professor, Chancellor's Fellow, and an Associate Professor in the Department of Criminology, Law and Society (and, by courtesy, Sociology and Public Health) at the University of California, Irvine, United States.

(c) 2022 Russell Sage Foundation. Friedman, Brittany, Alexes Harris, Beth M. Huebner, Karin D. Martin, Becky Pettit, Sarah K.S. Shannon, and Bryan L. Sykes. 2022. "What Is Wrong with Monetary Sanctions? Directions for Policy, Practice, and Research." RSF: The Russell Sage Foundation Journal of the Social Sciences 8(1): 221-43. DOI: 10.7758/RSF.2022.8.1.10 This research was funded by a grant to the University of Washington from Arnold Ventures (Alexes Harris, PI). We thank the faculty and graduate student collaborators of the Multi-State Study of Monetary Sanctions for their intellectual contributions to the project. Partial support for this research came from a Eunice Kennedy Shriver National Institute of Child Health and Human Development research infrastructure grant, P2CHD042828, to the Center for Studies in Demography and Ecology at the University of Washington. This research was also supported by grant, P2CHD042849, Population Research Center, awarded to the Population Research Center at the University of Texas at Austin by the Eunice Kennedy Shriver National Institute of Child Health and Human Development. The content is solely the responsibility of the authors and does not necessarily represent the official views of the National Institutes of Health. Authorship is alphabetical. Direct correspondence to: Becky Pettit, at bpettit@utexas.edu, Department of Sociology, University of Texas at Austin, United States.

Open Access Policy: RSF: The Russell Sage Foundation Journal of the Social Sciences is an open access journal. This article is published under a Creative Commons Attribution-NonCommercial-NoDerivs 3.0 Unported License. 
"[T]he moderate reform would be make it fair.

The better reform would be get rid of it."

—California Attorney

Monetary sanctions are an integral and increasingly debated feature of the American criminal legal system. Tens of millions of people each year are assessed fines, fees, and other costs stemming from legal involvement triggered by traffic stops to felony convictions. Policing agencies, criminal courts, and probation and parole agencies often assess monetary sanctions and, along with private collection agencies in some states, collect them. The widespread use of monetary sanctions as a form of punishment for criminal offenses has generated billions of dollars in revenue while generating a massive amount of debt among those unable to pay.

Monetary sanctions are often characterized as a less punitive sanction than other forms of punishment, such as incarceration (Greene 1988; Morris and Tonry 1991; Petersilia 1999; Tonry and Lynch 1996). Nora Demleitner (2005) argues that monetary sanctions are an integral part of community reintegration for people involved in the criminal legal system, writing that they: "allow-and even require-individuals to be employed, pay fines and make restitution, pay taxes, and assist their families. Such demands are crucial to allowing them to regain their place in society" (Demleitner 2005, 346). Jurisdictions across the United States rely on revenue from monetary sanctions to fund a wide variety of justice and non-justice related purposes, including courts and other government operations (Sances and You 2017; Martin 2018; Pacewicz and Robinson 2020).

Research shows, however, that large numbers of people are unable to pay their fines and fees, and courts may be paying more in attempts to collect or sanction nonpayment than they will ever generate as revenue (Menendez et al. 2019). Some 6 percent of adults in the United States report debt from court costs or legal fees, and that number rises to 20 percent of people with an immediate family member in jail or prison (Federal Reserve 2020). At the state level, a recent analysis finds that total court debt is at least $\$ 27.6$ billion. Importantly, this analysis draws on data only from the twenty-five states that could provide at least partial data about the amounts owed (Hammons 2021). In just three states, the amount of outstanding debt increased by $\$ 1.9$ billion between 2012 and 2018 (Menendez et al. 2019). At the federal level, $\$ 100$ billion of unpaid restitution has been deemed uncollectible due to defendants' inability to pay (GAO 2018).

Monetary sanctions centralize money as a key determinant of just outcomes, including proportionality, finality, and specificity in punishment. Existing patterns of economic inequality in the United States, including racial disparities in income and wealth, draw attention to how monetary sanctions undermine the premise of equality before the law. Monetary sanctions allow people with financial means to resolve debts, fulfill sentences, and thereby absolve themselves of criminal wrongdoing. At the same time, unpaid monetary sanctions contribute to extended system involvement and legal entanglements (Martin, Spencer-Suarez, and Kirk 2022, this volume) that uniquely disadvantage certain subgroups of the population on the basis of ability to pay (Bing, Pettit, and Slavinski 2022, this volume; Sanchez et al. 2022, this volume; Stewart et al. 2022, this volume; Sykes et al. 2022, this volume; Harris 2016; DOJ 2015). The Ferguson Commission report concluded that legal financial obligations were exploitative and "disproportionately harmed defendants with low incomes" (Ferguson Commission 2015, 93).

In this article, we consider how features of law, policy, and practice across states, and within them, shape just outcomes and equality before the law. Emerging research, including that featured in this double issue, offers important insight into the law governing monetary sanctions, how monetary sanctions are levied, and how their imposition concentrates their negative impacts especially among low-income individuals and people of color. We compare the policies and practices across and within eight states, drawing attention to variability in monetary sanctions. This variability helps illustrate how monetary sanctions shape legal outcomes and their consequences. The design of monetary sanctions and common practices undermine individuals' rights and fuel inequality in the effects of penal debt. These observa- 
Table 1. Number and Rate of Adults Under Correctional Supervision, Study States, 2014

\begin{tabular}{lccrr}
\hline State & $\begin{array}{c}\text { Adults on } \\
\text { Probation or } \\
\text { Parole }\end{array}$ & $\begin{array}{c}\text { Community } \\
\text { Supervision } \\
\text { Rate }\end{array}$ & $\begin{array}{c}\text { Adults in } \\
\text { Prison or } \\
\text { Local Jail }\end{array}$ & $\begin{array}{c}\text { Incarceration } \\
\text { Rate }\end{array}$ \\
\hline California & 382,600 & 1,280 & 207,100 & 690 \\
Georgia & 491,800 & 6,430 & 91,000 & 1,190 \\
Illinois & 151,800 & 1,530 & 67,200 & 680 \\
Minnesota & 104,300 & 2,490 & 16,200 & 390 \\
Missouri & 65,800 & 1,400 & 43,700 & 930 \\
New York & 149,100 & 960 & 77,500 & 500 \\
Texas & 496,900 & 2,480 & 219,100 & 1,090 \\
Washington & 104,000 & 1,890 & 30,900 & 560 \\
Sampled states total/average & $1,946,300$ & 2,308 & 752,700 & 754 \\
U.S. total/average & $4,708,100$ & 1,910 & $2,188,000$ & 890 \\
\hline
\end{tabular}

Source: Authors' tabulation based on Kaeble et al. 2016.

Note: Rates per hundred thousand adult residents.

tions lead us to offer a number of specific recommendations to mitigate some of the most harmful effects of monetary sanctions and advance future research.

\section{HOW MONETARY SANCTIONS}

\section{THWART JUST OUTCOMES}

Equality under the law is axiomatic to the U.S. criminal legal system. Although social and economic characteristics should not determine justice outcomes, ample evidence reveals how factors such as race, gender, and wealth can substantially affect whether and how people come into contact with the criminal legal system and the impact of that contact on people's lives (Miethe and Moore 1985; Shannon et al. 2017). In the United States, the connections between race, poverty, criminalized behavior, and punishment are intractable (Wacquant 2009) just as the connections between race, poverty, and policing are well established (Miller 2008; Stuart 2016). Because they directly bear on wealth, monetary sanctions reify and exacerbate racial inequalities in the criminal legal system while undermining equality before the law and fairness in outcomes.

\section{Unequal Exposure}

Exactly how and how many people are brought into the criminal legal system varies dramatically across states and provides leverage to understand how monetary sanctions influence fairness in case outcomes. Throughout this article, we summarize and consider implications from an eight-state study of monetary sanctions (for methods and aims, see Harris, Pattillo, and Sykes 2022, this volume). Table 1 shows that fully one-third (34 percent) of adults incarcerated in prisons and jails and more than twofifths (41 percent) of adults under communitybased supervision in the United States were in these eight states in 2014. California, Illinois, Minnesota, New York, and Washington had incarceration rates below the U.S. average; Georgia, Missouri, and Texas had rates above it. Whereas roughly one in 256 adults in Minnesota was incarcerated in 2014, Georgia incarcerated roughly one in eighty-four.

Table 1 further shows variability in exposure to probation and parole. In Missouri, 65,800 adults were under the supervision of probation and parole agencies, also termed community supervision, relative to nearly a half a million in both Georgia and Texas. The rate of community supervision was lowest in New York, where 960 per hundred thousand were on probation or parole, and highest in Georgia, where 6,430 per hundred thousand-more than 6 percent of the adult population-were under the surveillance of probation and parole agencies. Three of the states (Georgia, Minnesota, and Texas) had parole and probation rates above the U.S. average. Five had rates below the average. 
Traffic stops and other misdemeanors that do not involve jail time are the modal form of criminal legal contact (Natapoff 2018). Annually, tens of millions of people are pulled over by police in traffic stops; approximately half of them receive a citation (Langton and Durose 2013). Those citations commonly involve fines, fees, and other monetary sanctions (see also Huebner and Giuffre 2022, this volume). In states where traffic tickets are classified as criminal offenses, such as Georgia, Missouri, and Texas, an unpaid ticket can further expose people to additional criminal legal sanctions. Even in states where traffic violations are not classified in criminal law, unpaid tickets can incur a wide range of civil penalties. Unpaid criminal legal debt can precipitate police contact because courts issue warrants for failure to pay or issue capias pro fine warrants for failure to appear in court to address outstanding obligations (Natapoff 2018).

Although the number of people entering America's prisons and jails has declined in recent years (Carson 2020), the number of people subject to legal fines and fees has grown. Estimates suggest that 66 percent of incarcerated people have been sentenced to pay some amount of money to the courts or other criminal legal agencies, up from 25 percent in 1991 (Harris, Evans, and Beckett 2010, 1769). Millions more people are assessed fines and fees for traffic tickets and other misdemeanors that do not involve jail time (Mayson and Stevenson 2020; Natapoff 2018), though these penalties may lead to further entanglements in the criminal legal system (Huebner and Shannon 2022, this volume). The revenue incentive of monetary sanctions plays a role in some traffic stops (Brett 2020). The Department of Justice investigation of the Ferguson (Missouri) Police Department provides a poignant example, finding that the city finance director wrote to both the police chief and the city manager explicitly urging more ticket writing for city income (DOJ 2015). ${ }^{1}$

\section{Uneven Assessment}

The United States has no single coherent set of laws, policies, or practices guiding the imposition and enforcement of legal financial obligations. Thus legal fines and fees, much like other forms of surveillance and punishment, differ in important ways across and within states (Harris, Evans, and Beckett 2010; Harris 2016; Martin et al. 2018). Sarah Shannon and her colleagues (2020) find that across the eight states in this project, the process of punishment is highly varied across and within jurisdictions, the process is not transparent, and that noncompliance can precipitate significant debt and extralegal consequences. Karin Martin and her colleagues (2018) show the ubiquity of statutes governing legal fines and fees across states but also draw attention to differences in the extent to which state statutes mandate their imposition for felony and misdemeanor cases, provide opportunities for waivers, and offer alternative mechanisms of compliance.

Differences in key legal provisions governing monetary sanctions across states can help explain variability in assessment and impact. Table 2 shows that all states, for example, require judges or other court personnel to assess ability to pay before making a determination of willful noncompliance, enhancing monetary sanctions with additional penalties, or revoking probation. Despite all states' explicit recognition of differential ability to pay, variability in when ability to pay is determined is significant. For example, only in Washington must ability-to-pay legal financial obligations be considered at the time of sentencing. In other states, such as Texas and Missouri, the burden rests on the person sentenced to request a hearing regarding their ability to pay, which in Texas they may only do thirty days after sentencing. In still other states, the ability to pay may only become relevant after people default on their legal financial obligations, at which time the court may need to determine whether nonpay-

1. Police chief: "unless ticket writing ramps up significantly before the end of the year, it will be hard to significantly raise collections next year.... Given that we are looking at a substantial sales tax short fall, it's not an insignificant volume." City manager: "Court fees are anticipated to rise about $7.5 \%$. I did ask the Chief if he thought the PD could deliver $10 \%$ increase. He indicated they could try." 


\begin{tabular}{|c|c|c|c|c|}
\hline State & Ability to Pay Hearings & Waivers & $\begin{array}{c}\text { Open } \\
\text { Records }\end{array}$ & $\begin{array}{l}\text { Standard fo } \\
\text { Automated } \\
\text { Court Data }\end{array}$ \\
\hline California & $\begin{array}{l}\text { No, but the presentencing } \\
\text { report lists income/assets }\end{array}$ & $\begin{array}{l}\text { Depends on the offense } \\
\text { statute }\end{array}$ & No & No \\
\hline Georgia & No & $\begin{array}{l}\text { At judge's discretion except for } \\
\text { mandatory fines, fees, } \\
\text { surcharges }\end{array}$ & Yes & No \\
\hline Illinois & $\begin{array}{l}\text { No, mandatory post-conviction } \\
\text { hearings to explain } \\
\text { nonpayment, cover balances, } \\
\text { and requests for payment }\end{array}$ & $\begin{array}{l}\text { Full waivers for "assessments" } \\
\text { only and must apply within } \\
\text { thirty days of sentencing }\end{array}$ & Yes & No \\
\hline Minnesota & No & $\begin{array}{l}\text { Fines can be reduced to } \$ 50 \\
\text { and judges can allow } \\
\text { community service in lieu of } \\
\text { the fine. Surcharges and law } \\
\text { library fees are not waivable }\end{array}$ & Yes & Yes \\
\hline Missouri & Must be granted if requested & Allowed at judges' discretion & Yes & No \\
\hline New York & $\begin{array}{l}\text { Financial Hardship Hearings } \\
\text { after failure to pay on time }\end{array}$ & No & Yes & No \\
\hline Texas & After thirty days & Allowed at judges' discretion & Yes & No \\
\hline Washington & At sentencing & $\begin{array}{l}\text { At judge's discretion except for } \\
\text { mandatory fines and fees }\end{array}$ & Yes & Yes \\
\hline
\end{tabular}

Source: Authors' tabulation.

ment was "willful" and thus subject to additional sanctions, as in Illinois (see Fernandes, Friedman, and Kirk 2022, this volume).

How ability to pay is determined also diverges across states. Missouri state statutes instruct courts to consider the financial resources of a defendant when making judgments but a formal assessment or documentation is not required. ${ }^{2}$ Judges in Washington have the discretion to assess whether people with legal financial obligations are capable of making minimum monthly payments, but are still required to impose the mandatory minimum assessment of $\$ 500$ per felony conviction. Texas has a clearly articulated standard for the determination of indigence for court-appointed counsel, but judges retain discretion in determining eligibility to pay legal financial obligations (see also Harris et al. 2017).

Statutory allowances for waiving monetary sanctions also vary widely by state. In California, the ability to waive monetary sanctions depends on the offense statute. In three statesIllinois, New York, and Washington-the law does not allow for the waiver of mandatory surcharges, which are those states' dominant form of monetary sanctions (see Martin, SpencerSuarez, and Kirk 2022, this volume; Harris 2016). In other states, judicial discretion is paramount, including Georgia, Minnesota, Missouri, and Texas. Nevertheless, some statutory limits on such waivers are in place, with some statutes disallowing the waiver of some or all fees (Georgia, Minnesota) and surcharges or 
only allowing reduction of the fine to a certain amount (Minnesota).

\section{Disparate Impact}

Variability in the design of monetary sanctions across states contributes to disparate experiences with and effects of monetary sanctions. Although legal financial obligations are routinely imposed for misdemeanor and felony criminal legal involvement, important differences in how they are assessed, whether and to what extent they are waived, and how collections are handled can lead to differential impact and trigger a wide range of additional sanctions. Common practices undermine individuals' rights and fuel inequality in the effects of unpaid monetary sanctions. Differences in the design and implementation of monetary sanctions across states and within them help reveal how the negative impact of monetary sanctions, and thus disproportionate punishment, is concentrated among people with low incomes and, by extension, people of color (Bing, Pettit, and Slavinski 2022, this volume) and people receiving public assistance (Sykes et al. 2022, this volume). Recent work further illustrates how the negative impacts of legal financial obligations are concentrated among immigrants (Sanchez et al. 2022, this volume) and Native Americans (Stewart et al. 2022, this volume).

Unpaid monetary sanctions can prompt additional criminal legal sanctions, incur added financial penalties and surcharges, result in the extension or revocation of probation, and lead to the issuance of arrest warrants which can result in jail time (Harris 2016; Harris et al. 2017; Huebner and Shannon 2022, this volume; Ruhland, Homes, and Petkus 2020). In some states, unpaid legal fines and fees can also set in motion civil penalties including the revocation of drivers' licenses, wage or asset garnishment, and even civil lawsuits (see Fernandes, Friedman, and Kirk 2022, this volume). Katherine Beckett and Naomi Murakawa (2012) highlight how legal fines and fees are found in civil and criminal systems, and Alexes Harris (2016) illustrates the powerful role court clerks, or other administrative personnel, play in the collection and enforcement of monetary sanctions. As a result, as Beckett and Murakawa (2012) suggest, legal fines and fees constitute a "shadow carceral state," obscured in studies of conventional sentencing and sanctioning processes yet with wide-ranging and enduring effects.

Table 3 displays how driving on a suspended license can produce a disparate impact for people of varying economic means within each state. Specifically, the amount due at sentencing can vary from a low of $\$ 62$ in Texas to a high of \$3,480 in California. In Minnesota, a state with a low incarceration rate (see table 1 ), has financial penalties for traffic offenses that can cost several hundreds of dollars. Variation also exists across states in the length of time it would take to pay off fines and fees for the same charge. Assuming a payment plan of $\$ 50$ per month, it would take considerable time to pay off debt associated with driving on a suspended license in some states. For instance, in only four-Minnesota, Missouri, New York, and Texas-would it take fewer than eighteen months to pay off associated fines and fees.

Table 3 also reveals how fees, surcharges, and other additional costs, including interest, penalties, and administrative costs, can dramatically increase the total monetary sanctions owed. In California and Washington, the maximum fine is less than half of the maximum total assessment for driving on a suspended license. In only two states, Missouri and New York, do fines constitute more than threequarters of the maximum allowed assessment. People with financial means may pay off monetary sanctions on time and without penalty; yet people without such means face additional costs that may extend criminal legal system involvement as well as force hard decisions on whether to pay.

Monetary sanctions amplify the disparities in criminal legal system contact along the lines of race and wealth. Recent estimates show that the median wealth of white families is around $\$ 190,000$, of African American families slightly more than $\$ 24,000$, and of Latinx families about $\$ 36,100$ (Federal Reserve 2020). The amount available in liquid savings also differs significantly by race. Whereas the typical Black or Latinx family has less than $\$ 2,000$, the typical white family has more than $\$ 8,000$ (Federal Reserve 2020). At the same time, African Americans are more likely than white Americans to 


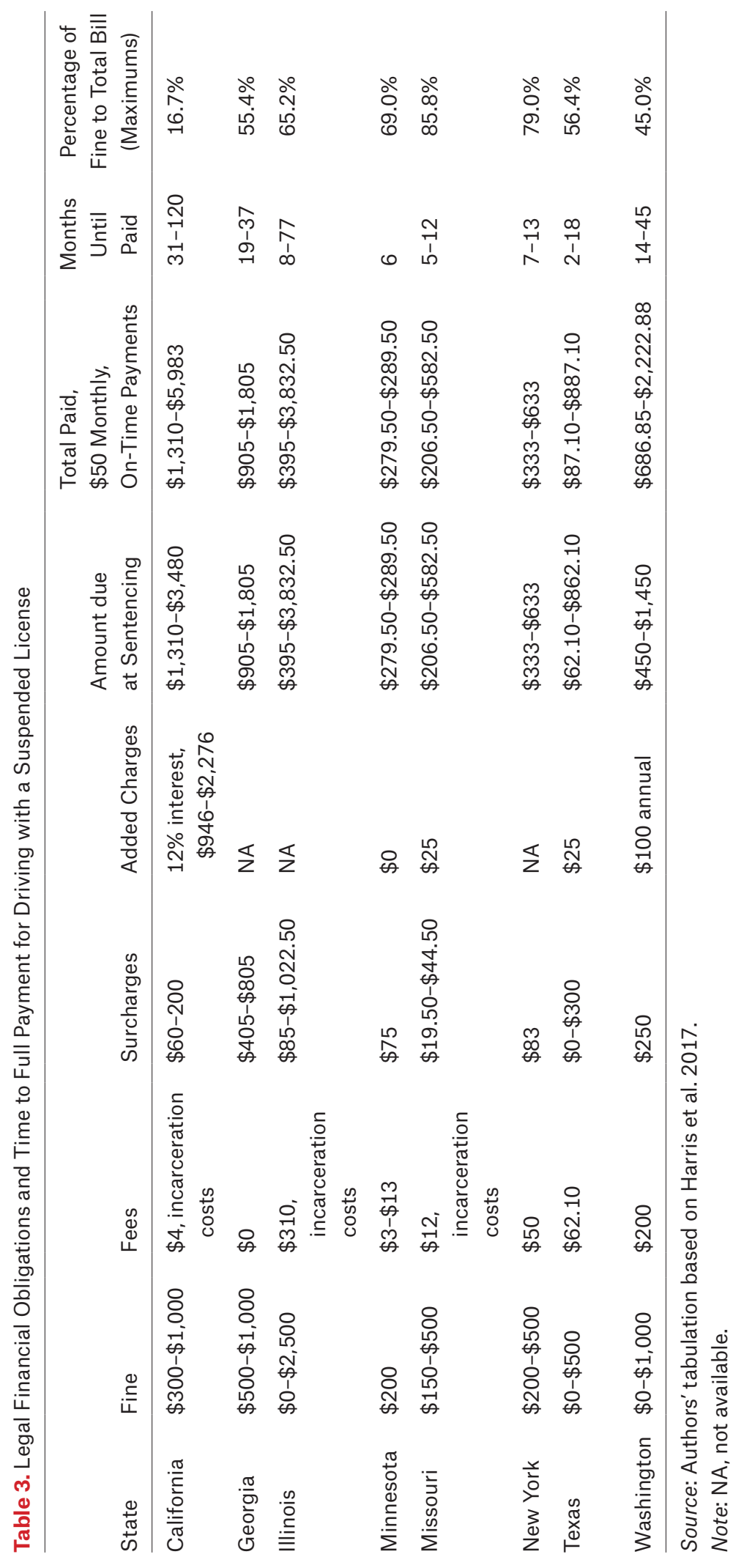


be arrested and convicted and African American adults are 5.9 times as likely and Latinx adults are 3.1 times as likely to be incarcerated than white adults (Carson 2020). Considering these factors together, along with the ubiquity of monetary sanctions for every offense and at every level of government, reveals the significant potential of criminal legal debt to worsen problematic disparities.

\section{LIVED EXPERIENCES WITH}

\section{MONETARY SANCTIONS}

How the design and practice of monetary sanctions shape fairness in outcomes and equality before the law is further evident in ethnographic observations in courtrooms and interviews with people assessed monetary sanctions, attorneys, judges, and other people tasked with enforcing them. Our research shows how the lack of a single coherent set of laws, policies, or practices guiding the imposition and enforcement of monetary sanctions generates significant variability in experiences with and effects of monetary sanctions across states and within them. Legal financial obligations are routinely imposed for misdemeanor and felony criminal legal involvement across all eight states, yet important variations are evident in exposure to monetary sanctions and states' reliance on revenue generated from monetary sanctions. ${ }^{3}$

How monetary sanctions are assessed, whether and to what extent they are waived, and how collections are handled have important consequences for people's experiences with the criminal legal system. People who are assessed monetary sanctions and cannot pay them often experience the penal debt harshly, undermining conceptualizations of monetary sanctions as humanizing or an intermediate sanction (Greene 1988; Morris and Tonry 1991; Petersilia 1999; Tonry and Lynch 1996). In the following section, we highlight several dimensions along which fairness in outcomes and equality before the law are compromised in practice, as shown through the lived experiences of the people we interviewed and courtrooms we observed.

\section{Unequal Punishment}

Individuals who have the means to comply with monetary sanctions are, for many offenses, able to pay fines, fees, and other monetary sanctions with the court clerk in person, online, or by mail and therefore have no further involvement with the court (see Bing, Pettit, and Slavinski 2022, this volume). If someone is unable to pay, or needs accommodations, the process can become complicated and lead to additional sanctions. Failure to pay, comply with the payment schedule, or to attend court dates can lead to additional legal, financial, and civil consequences. For those who are not able to pay, the process of compliance with the law is difficult (Martin, Spencer-Suarez, and Kirk 2022 , this volume). The sheer variability in processes across states and within them is remarkable. Several study participants reported that they were issued a warrant for failure to appear at a court date when they had not received documentation of the court date.

Being unable to pay monetary sanctions can incur a wide range of "poverty penalties," which add costs, measured in time or money, simply as a consequence of needing more money or additional time to pay. For example, in Missouri, individuals who do not have the means to comply with a financial sanction or who would like to contest the associated charge are required to attend court for a hearing. Several study participants reported negotiating payment plans with the court so that they could spread the payment out over time. Some courts allowed individuals to make their scheduled payment online with a fee or with the clerk, if the payment was made in advance of the next payment. One study participant reported that she had to pay to get a payment plan developed and then had to pay an additional fee for the show cause hearing: "Just to get any of the judge's time, for whatever it might be, you have to pay them $\$ 22.50$. If you can't pay, then you have to go in front of the judge, where you have to pay anyway." Several participants reported having to make multiple trips to the courthouse to set up a payment plan and to submit payment, and some courts levied fees for each

3. For details on revenues generated by fines, fees, and forfeitures, see table A1. 
hearing (see Huebner and Giuffre 2022, this volume).

In other courts, individuals were required to attend a payment docket to check in with the judge and submit payment. A similar process is used in New York, where all courts have a regularly scheduled financial hardship hearing or full-time courtrooms dedicated to hearing payment issues. Illinois described this process as pay or appear, judges using discretion during the hearing to decide whether the person's nonpayment is willful. The challenges of staying up to date with payment becomes even more difficult the longer a person is on a payment plan or if they move.

Court observations reveal that individuals were rarely put on warrant status because of failure to pay, but if individuals did not attend court they were at risk of a warrant for failure to appear. In Texas courtrooms, we observed judges routinely issuing capias pro fine warrants for failure to appear without any determination of ability to pay or willfulness. Field notes from one municipal court document the determinations: "The judge ... begins going down the list [of cases on the docket] rapid fire.... everyone who showed up to see the clerk [has] their charges dismissed and everyone who didn't [show up] gets issued a warrant for failure to appear. 'You gotta be here to win,' [the judge] jokes as he stamps and signs the papers." Another set of field notes documents a judge issuing thirteen capias pro fine warrants for failure to appear in less than half an hour. $^{4}$

We observed similar processes in California, Missouri, and New York. In California, for example, the court presumes that people have adequate transportation to the court, a key barrier for many study participants; however, these assumptions matter for whether someone misses court and has a failure to appear warrant issued. Warrants were regularly ordered for peo- ple who missed court in California, and many study participants had to travel over an hour in heavy traffic using public transportation to attend. In Missouri, if individuals were unable to attend court because they were incarcerated, a warrant was still issued because no central data system tracks incarceration.

Many study participants reported that they did not have the information they needed to successfully navigate the criminal legal system and manage their monetary sanctions. This lack of information and related lack of transparency of criminal legal processes is aggravated by poor, or proprietary, data management systems. For example, in Missouri the state maintains one data system for state courts that includes information on sentencing but often little information on the nature of the outstanding debt. In addition, most costs are assessed at the municipal court level and each court maintains its own system. During court observations, we rarely observed people reminded of the requirement to opt-in to the state court reminder system, and even more rarely observed people opting in. Thus individuals sentenced to debt often relied on contacting the courts directly to get information, but the court was rarely open, an issue of particular concern for smaller municipal courts.

The challenge of compliance with payment requirements was even more difficult for people who owed money in multiple jurisdictions. A participant in Missouri owed money in several courts. When asked whether he knew how to find out how much he owed, he said, "No. I don't know. I know if you probably just call down there and they tell you what all you owe or whatever. If you got a lot of different municipalities, you gonna have to call a lot of different places, and you might call down to up there, up the street to the court building and somebody might hang up on you, have you on hold for twenty minutes, and then they answer the

4. Data from court records in Texas show that these are not isolated cases and indigency waivers are rarely granted for minor misdemeanors (Class C) and that arrest warrants and satisfying fines and fees through time served is common. At the county level, fewer than 1 percent of misdemeanor cases are granted an indigency waiver, a particularly surprising finding in a state with a poverty rate well above the national average. An equally small proportion of cases have collections waived. At the same time, on average across counties 8.8 percent of cases are satisfied by jail credit and nearly half (47.2 percent) of cases in one county are satisfied by spending time in jail (see also Pattillo and Kirk 2021). 
phone and hang up. So you gotta call back and do it all over again."

Even people who are trying to satisfy monetary sanctions often encounter unarticulated and unanticipated costs associated with compliance. Online payment vendors across Illinois include an undisclosed vendor fee. These include but are not limited to convenience fees charged by Judici E-pay. Illinois state law allows counties to charge up to a $\$ 5$ fee for payments made by credit card or through a third-party vendor. ${ }^{5}$ After the Ferguson Commission hearings and report, municipalities in Missouri were required to develop websites that allow for online payment. However, like in other states, the online payment systems come with an additional service fee, further adding to the cost of compliance.

The wide range of civil and criminal penalties triggered by failure to pay monetary sanctions can also result in a cascade of additional costs. Driver's license suspension, revocation, or denial of renewal can be costly. Across the states, the cost for applications to reinstate driver's licenses ranged from \$30 (Minnesota) to $\$ 150$ (Washington), many requiring full payment of outstanding fines and fees before reinstatement (Illinois). ${ }^{6}$ In Missouri, the state allows additional fees ranging from $\$ 20$ to $\$ 150$. In Texas, people are required to pay a $\$ 30$ fee before reinstatement. In New York, "termination of suspension" fees range from $\$ 50$ to $\$ 100$. Although the law on the relationship between unpaid monetary sanctions and the Department of Motor Vehicles (DMV) or DMV equivalent is rapidly changing in response to legal challenges, ${ }^{7}$ many people we interviewed detailed the hardships they experienced when outstanding legal debt prohibited them from having, or renewing, a driver's license.
Multiple system involvement-such as having child-support obligations in addition to criminal legal debt-can further complicate system involvement and incur additional costs. Several people we spoke with were jailed for failure to pay either child support or criminal monetary sanctions. The degree to which criminal courts and child welfare agencies prioritize who should be paid first is a thorny issue, but the consequences for nonpayment in either system may compound legal entanglements. In one notable exchange from a Georgia, a participant summarized their experience that led to losing their driver's license because they owed child support:

I mean they just send you a letter saying that. ... Well one thing I didn't know was that, I thought it was something they would automatically take care of with me being incarcerated, my child support was still going. Of course, I'm falling behind and I'm not knowing it. Honestly, I'm thinking if I'm locked up it would stop because you know I can't pay if I'm locked up. But I didn't know this about two or three different times and I fell so far behind. I get a letter your license is suspended for child support.

The participant thought that he would have the costs covered or paused while in prison and went on to say that it took twenty years to eventually get his license reinstated.

Garnishment of commissary accounts in prison and wages from work release also emerged as a concern. Study participants from California, New York, and Missouri, states notable for their generous allowances for garnishing commissary accounts, experienced significant material hardship—going without food or

5. Illinois Clerks of Courts Act, 705 ILCS 105/27.3 (2019), https://www.ilga.gov/legislation/ilcs/documents/0705 01050K27.3.htm (accessed August 12, 2021).

6. Minnesota, "Resolve Canceled License," https://dps.mn.gov/divisions/dvs/Pages/search-dvs.aspx?filter1 =Driver\%27s\%20License\&filter $2=$ Class $\% 20$ A \%20-\%20Commercial\%20Driver\&filter3=Resolve\%20 Canceled\%20License (accessed August 12, 2021); Washington, “Types of Suspensions," https://www.dol.wa .gov/driverslicense/suspensions.html (accessed August 12, 2021); and Illinois, "Driver's License Reinstatement Fees," https://www.cyberdriveillinois.com/departments/drivers/drivers_license/dlreinstatement.html (accessed August 12, 2021).

7. On debt-based driver's license suspensions, see Free to Drive, "Resources," https://www.freetodrive.org /resources/\#page-content (accessed August 12, 2021). 
personal hygiene products-because their commissary accounts were drained to satisfy outstanding legal debt. In Washington, study participants were concerned about the garnishment of wages earned during work release when they also reported having to pay fees well in excess of their earned income in order to participate in work release. A participant from Minnesota cited their experience with the garnishing of already low wages as a reason to be cynical about the system: "When I went to prison, I'm making twenty-five cents an hour, and they took half. So, you're only making twelve and a half cents an hour, because they took half. Half for gate fee, for restitution, what else was in there, I forgot. DOC imposed some kind of fine, some kind of surcharge, back then. On money that was sent in, they were taxing it 10 percent or something. So, if my grandma sent me $\$ 100$ bucks, I only got $\$ 90$ of it, because they took \$10."

People unable to pay legal debt experience an abundance of legal, social, and financial consequences until they are able to pay in full (see also Huebner and Shannon 2022, this volume, Harris and Smith 2022, this volume, Pattillo et al. 2022, this volume, Sanchez et al. 2022, this volume, Boches et al. 2022, this volume; Sykes et al. 2022, this volume). Extended legal entanglements, including long-term supervision, was common for people we interviewed who were assessed monetary sanctions in addition to a prison or jail term. Our research clearly illustrates how the system of monetary sanctions serves as an unequal and indeterminate punishment for people who are too poor to pay in full.

\section{Arbitrary and Excessive}

The sheer variability in monetary sanctions across states for a given violation highlights their arbitrary nature (see table 3). Research has also drawn attention to the excessive nature of some monetary sanctions (see, for example, Harris 2016; Pattillo and Kirk 2021). Recent court rulings have concurred. Timbs $v$. Indiana found that asset forfeiture may contradict the excessive fines clause of the Eighth Amendment. ${ }^{8}$ In the majority opinion, Justice Ginsburg wrote that monetary sanctions should "be proportioned to the wrong" and financial penalties should "not be so large as to deprive [a person] of his livelihood," making explicit reference to Black Codes used disproportionately to convict, fine, and "subjugate newly freed slaves and maintain the prewar racial hierarchy" (5-6).

The arbitrariness of monetary sanctions is exemplified by practices around ability-to-pay hearings. Although most state statutes allow for the waiver of at least some monetary sanctions in cases when a defendant is unable to pay, individuals who lacked legal counsel were often ill equipped to assert their indigence and were rarely granted waivers. In fact, some participants reported that they were discouraged from seeking an ability-to-pay hearing and sometimes provided misinformation from court personnel. When we asked James, a veteran living with physical disabilities who owed more than $\$ 1,500$ for five tickets he received in one traffic stop, whether he has tried to get an indigence hearing to get the fees waived, he replied, "[The clerk] told me that if I wanted to do that, I'd have to hire my own private lawyer, which also I don't have enough money for. I don't think Legal Aid takes these cases. . . . I'm pretty sure they don't take traffic ticket cases. They'd be overwhelmed if they did."

How judges determine indigence or willful nonpayment varies across jurisdictions. In Missouri, this discretion is commonly based on questions about the person's lifestyle to determine whether they are spending funds on "leisure," such as buying cigarettes rather than paying the court. Moreover, field notes indicate that even defendants who clearly met the state standard for indigence by relying on Social Security Income (SSI) were routinely denied indigence waivers. Instead, they were commonly offered a monthly payment plan (\$25 per month was standard) or the opportunity to satisfy fines and fees through community service. In Texas, one judge claimed that even though a defen-

8. Timbs v. Indiana, 139 S. Ct. 682 (2019).

9. Quoting Justice Ginsburg in reference to Browning-Ferris Industries v. Kelco Disposal, 492 U.S. 257 (1989), at 271 (Timbs v. Indiana). 
dant was receiving SSI and food stamps, she could have used her tax refund to pay her outstanding legal debt. Field notes record the exchange: "The judge asks why she didn't pay. She says 'you had 30 days to pay and you didn't pay it.' The judge asks the defendant again, 'When did you get your tax refund?' The judge orders [the defendant] to pay $\$ 25$ every 30 days. She tells [the defendant] that 'you had the ability to pay.' 'I'm not going to find you indigent even though you're on the SNAP [Supplemental Nutrition Assistance Program] program and the CHIP [Children's Health Insurance Program] program."”

How monetary sanctions were collected and to whom payments were made varied greatly across the study sites and highlight how differential access to information and technology by which to pay can lead to disparate impacts. In some jurisdictions, people can pay their monetary sanctions online. In others, they must pay in person. Being able to pay monetary sanctions online can save people significant money, time, and hassle. However, many jurisdictions with online court payment systems charge people additional costs to use their credit cards and perpayment convenience fees. ${ }^{10}$ In Illinois, only some counties allow online payment. Cook County-the largest county by population in Illinois and the second largest by population in the United States-mandates that payments are made in person. Differences in how payments are managed have important consequences for amounts owed as well as the amount of time and resources people have to devote to satisfying their monetary sanctions (for a related discussion of procedural hassle in misdemeanor courts, see Kohler-Hausmann 2018).

A fundamental challenge to compliance is not having information about how much and how to pay. Many people we interviewed who owed legal debt reported that they have trouble finding information about their cases and determining how much they owe. Defense attorneys and people who owed debt suggested that the lack of information stems from archaic methods courts use, such as paper records (see also Huebner and Giuffre 2022, this volume).
New York State and several communities in Illinois did not maintain online information portals that provide information on payment, amount due, and compliance requirements. In New York, people are expected to keep track of what they owe and when; no payment notifications are sent after sentencing although warrants are regularly issued for nonpayment.

In many jurisdictions, clerk's offices handled payments whether delivered in person or online. Yet in others, collections were handled by probation offices or private collection agencies. Payments managed by probation set in motion additional forms of criminal legal surveillance and the involvement of private agencies introduced profit motives for enhancing collections (Huebner and Shannon 2022, this volume). In all Georgia courts, the primary mode of legal debt collection is probation or parole supervision. Collections at the felony level in Georgia occur through a centralized, statewide system for collections managed by a private company that charges a fee per transaction.

Variation was significant across states and jurisdictions on the usage of private collections agencies. The city of Seattle has a no-cost contract with a private collections agency. According to California and Missouri law, counties are responsible for the collection of monetary sanctions, though they may delegate some or all of the collection back to the courts and counties, and courts are allowed discretion in their collection practices, particularly when people are more than ten days late on a payment. In Texas, courts can use private collections agencies after sixty days of nonpayment. At the misdemeanor level, individuals on probation in Georgia and Missouri are often subject to collections through private probation companies that charge not only monthly supervision fees but possibly also extra fees for payments (Huebner and Shannon 2022, this volume).

\section{Expanded System Involvement}

Monetary sanctions expand system involvement for people who cannot pay them com-

10. See, for example, Seattle Municipal Court's payment portal (https://secure8.i-doxs.net/SeattleSMC, accessed August 12, 2021). 
pletely and quickly in several ways. First, monetary sanctions are levied in a wide range of situations from felony convictions to misdemeanor citations. In some states, they are levied in courts in addition to incarcerative sentences mandating jail or prison time, often extending system involvement after the completion of time served (Harris 2016). Legal fines and fees also accompany supervisory sentences requiring community service, probation, victim panel classes, drug and alcohol assessment and treatment, and anger management courses (Huebner and Shannon 2022, this volume; Harris, Smith, and Obara 2019; Pattillo and Kirk 2021). The assessment of monetary sanctions for low-level misdemeanors, including traffic citations, also widens the scope of criminal legal contact, involving tens of millions of people each year (Bing, Pettit, and Slavinski 2022, this volume; Needham et al. 2020).

The assessment of monetary sanctions in addition to prison and jail time, probation, or other sanctions can extend surveillance. Even after a term of supervision is completed, people unable to pay legal debt experience an abundance of legal, social, emotional, and financial consequences until they are able to pay in full (Harris and Smith 2022, this volume; Huebner and Shannon 2022, this volume). Extended legal entanglements, including long-term supervision, were common for people we interviewed who were assessed monetary sanctions in addition to a prison or jail term. At the same time, the costs associated with probation and other court-mandated programs could lead to indeterminate periods of surveillance.

At the time of sentencing, judges customarily impose the completion of programs and routine monitoring. The costs for courses for driving under the influence, anger management, drug and alcohol treatment, domestic violence, parenting, and antitheft classes are not systematically assessed or described at the time of sentencing. Similarly, the costs of surveillance and routine monitoring also remain unarticulated during the sentencing process. Many of these services leverage private companies to collect and to report compliance with program requirements ordered by the state, and their costs are fully revealed to individuals only when they seek to enroll and to complete the programs.
Worse, some participants reported having to restart their courses because of missed payments or unattended classes, increasing the total amount. The hidden costs of probation and program participation can dwarf the monetary sanctions associated with fines and fees for the offense and, unpaid, can prolong supervision (Huebner and Shannon 2022, this volume).

The criminalization of traffic violations in some states, including speeding tickets, has dramatically widened the scope and impact of monetary sanctions (Baumgartner et al. 2018; Bing, Pettit, and Slavinski 2022, this volume; Huebner and Giuffre 2022, this volume). In such states, a minor infraction can lead to insurmountable debt for those who cannot pay. In Georgia, Missouri, and Texas, getting pulled over for speeding is considered a criminal offense and subjects millions of people each year to extended legal entanglements if they are unable to pay (Huebner and Giuffre 2022, this volume). Even in states where minor traffic infractions are considered civil offenses, unpaid monetary sanctions can trigger a range of civil penalties.

One participant recalled how one traffic ticket triggered a cascade of others: "The first one was from failure to control speed. Then, after that one I had a failure to appear in court. Then, after that it was a failure to wear a seat belt. Then, a failure to appear to court . . . I can't remember each one." Legal fines and fees can be exceptionally difficult to resolve for people who are working poor. Deferred car repairs, such as a broken headlight, can trigger or exacerbate legal involvement. This participant, a middle-aged mother of two, went on to describe how all of the moving violations were issued in the same neighborhood while she was driving to work. On one occasion, she was pulled over because she had a headlight out. She explained that at first the officer told her it would just be a warning but after he ran her license and saw that she had a pending ticket, he issued her another: "Once he saw that I had prior tickets, he just gave me another, which made it kind of extremely difficult for me to even start a payment plan because now I have like three $\$ 500$ tickets. Mind you, I still have to take care of my kids, I still have to pay on my car note, I still have to do my everyday living on 
top of now having to pay like $\$ 1,500$ within three days for tickets."

\section{KEY POLICY RECOMMENDATIONS}

As our research shows, the design and practice guiding monetary sanctions widen the scope of criminal legal involvement, are experienced differently based on capacity to pay rather than evidence of wrongdoing or determination of culpability, and further contribute to inequality by amplifying punishment among those least able to pay. These observations lead us to offer specific recommendations to improve the administration of justice. They also raise important questions about whether it is an opportune time to consider abolishing monetary sanctions in the criminal legal system altogether.

Table 4 presents a summary of recommendations in relation to how they reduce the scope of monetary sanctions, eliminate practices that are arbitrary or result in excessive punishment, enhance equity, and advance research and policymaking. We draw on insights from recent work to consider how these recommended innovations in policy and practice can address goals of power shifting, defunding and reinvesting, and transformation to ultimately "dismantle the uniquely oppressive components of the law" (Clair and Woog 2022, 18-22). The table provides an intervention or recommendation, indicates key stakeholders, and offers examples. The table also makes note of trade-offs, or limitations, that may be associated with a given intervention or recommendation.

\section{Reduce the Scope of Monetary Sanctions}

Our first set of recommendations centers on reducing the scope of monetary sanctions. Over the past fifty years, the criminal legal system has adopted an outsized role. The United States continues to criminalize more infractions than ever, many of which involve monetary sanctions (Mayson and Stevenson 2020). A first, and very important, step in reducing the harms associated with monetary sanctions is to reduce or eliminate monetary sanctions whenever possible. Two strategies would go a long way to reducing such harms: decriminalizing traffic offenses in those states where a simple traffic ticket can entrap people in the criminal legal system; and ceasing the practice of assessing monetary sanctions in addition to custodial sentences that require spending time in prison or jail or supervisory sentences that mandate supervision by parole or probation agencies.

The abolition or substantial reduction in the use of monetary sanctions system must follow from a fundamental change in the way in which local courts and public services are funded. A true abolition of monetary sanctions would require a reduction or elimination of jurisdictional reliance on funding from monetary sanctions (Pacewicz and Robinson 2020). At the same time, we call for the elimination of the use of private agencies for debt collection and surveillance, an often-used tactic to minimize costs to state and local governments. Private companies have a perverse incentive to increase total punishment through its payment structures, because most contracts and funding depends on long terms of supervision and frequent violation reports (Huebner and Shannon 2022, this volume).

\section{Eliminate Arbitrary Practices and Excessive Monetary Sanctions}

To the extent that monetary sanctions remain a feature of the criminal legal system, our second set of recommendations targets arbitrary practices and excessive monetary sanctions that can be particularly harmful for people who do not have the economic means to pay. Specific strategies include mandating evaluations of ability to pay for all defendants at the time of sentencing, granting waivers of all costs (even those identified as mandatory) for people deemed unable to pay, and eliminating garnishment processes.

Ability-to-pay determinations should be based on a person's current income and expenses and no mandatory fines and fees should be levied against people without adequate or stable income to make regular payments. Furthermore, people living solely on federal means-based income or supplements should not be assessed any form of monetary sanctions (see Sykes et al. 2022, this volume). The excerpts from our field notes and interviews highlight the lack of ability-to-pay hearings held by judges both at the sentencing of fines and fees and at the assessment of nonpayment compliance hearings. Further, our research 


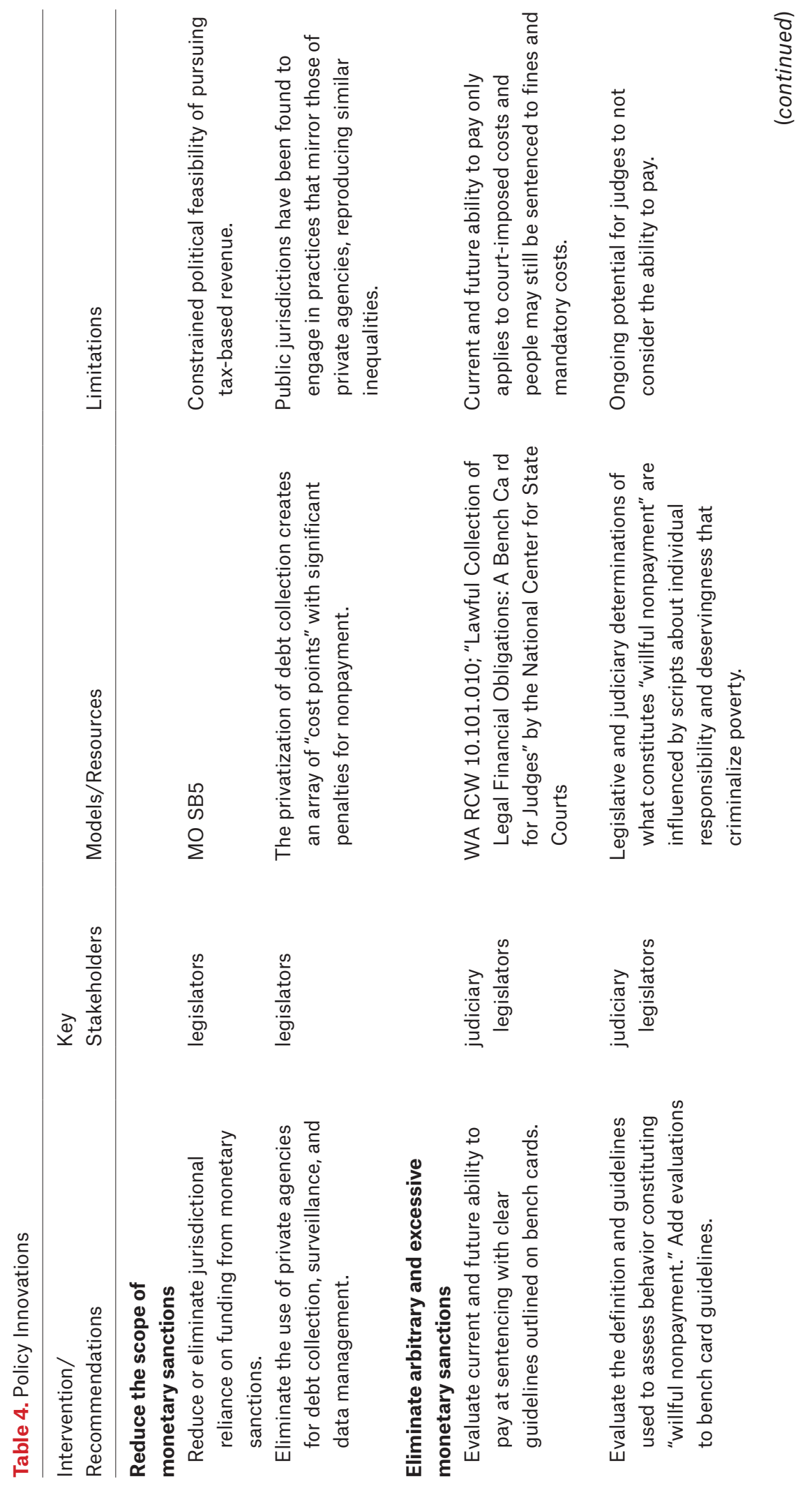




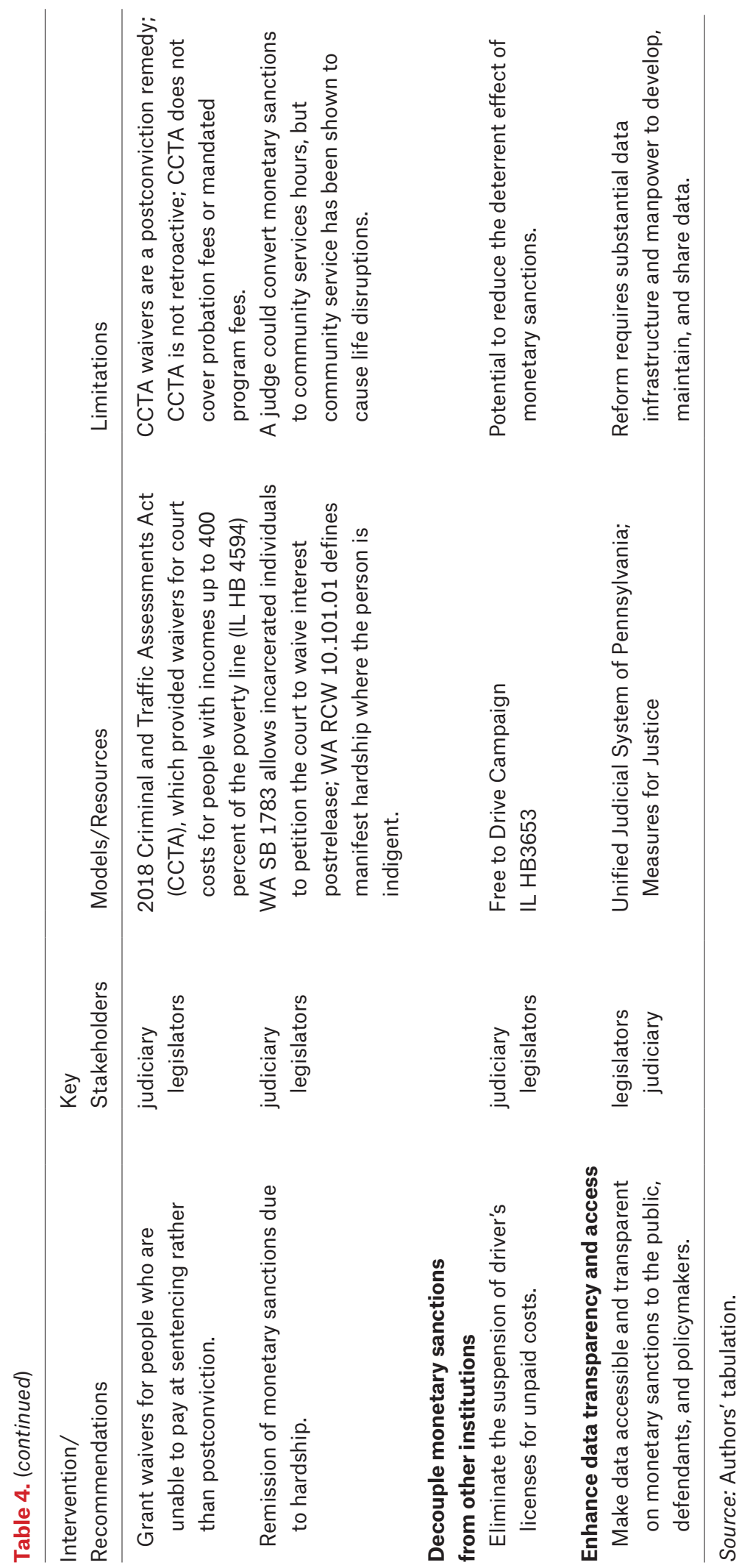


highlights the stress and strain individuals and their families experience as a result of their inability to pay their court debt and by the related court surveillance and collateral consequences such as the loss of drivers' licenses (Harris and Smith 2022, this volume).

States such as Illinois have recently overhauled their system of court costs by recognizing fees as user costs, explicitly identifying them as harmful to people who are indigent, acknowledging the lack of transparency in their imposition, and implementing reforms accordingly. In part to address the rise in appellate cases in which defendants challenge the fairness of specific legal fines and fees, the Access to Justice Act created the bipartisan Statutory Court Fee Task Force, which in 2016 released its findings and policy recommendations to the Illinois General Assembly and Illinois Supreme Court (Statutory Court Fee Task Force 2016). The candid report exposed the unfair, "byzantine" nature of fees as user costs, prompting the Illinois legislature to pass the 2018 Criminal and Traffic Assessment Act, which, among other things, provided waivers for court costs for people with incomes up to 400 percent of the poverty line (see Friedman and Pattillo 2019). ${ }^{11}$ Furthermore, the availability of waivers must be clearly articulated; additionally, courtroom personnel should receive bench cards and mandated training on how to implement new policies (see also Colgan 2019).

Garnishment of inmate accounts, prison wages, and other wages is unnecessarily and excessively punitive and can result in significant hardship for people assessed monetary sanctions as well as their families. Our interview data show that people experience garnishment as gratuitous and harmful and report that it undermines family relationships and motivation to work (Boches et al. 2022, this volume). Having the support of family members and friends is important, materially and symbolically, for people trying to survive while incarcerated and trying to reenter society after a period of incarceration. Garnishing commissary ac- counts and wages from work undermines family support and work effort and can have particularly acute consequences for people who are most disadvantaged.

\section{Enhance Equity by Revealing All Monetary}

Sanctions and Inter-Institutional Involvement Our third set of recommendations is designed to enhance equity to ensure that the negative effects of monetary sanctions are not concentrated on those unable to pay. Specifically, these include clearly articulating the full extent of monetary sanctions at the time of sentencing and decoupling monetary sanctions imposed by the criminal legal system from other institutions.

Costs of surveillance, routine monitoring, and court-mandated classes and program participation often are not articulated during the sentencing process. Many of these services leverage private companies to collect and to report defendant compliance with program requirements ordered by the state. Their costs are only fully revealed when people seek to enroll and complete these programs. The costs associated with court-ordered rehabilitation programs, courses, and surveillance should be clearly articulated at the time of sentencing. Moreover, whether charged by public or private entities, costs should be recorded in data collection systems. Articulating the full cost of sanctions at the time of sentencing and the collection of more comprehensive data on these costs have the potential to reveal disparities in both the assessment of monetary sanctions and assignment to diversionary programming.

Driving privileges must be decoupled from the repayment of monetary sanctions because the suspension and revocation of licenses for unpaid monetary sanctions incur disproportionate punishment to those who are unable to pay. Moreover, criminal courts should adjust payment expectations to accommodate legal financial obligations to noncustodial children or mandated child-support payments. If states prioritize and penalize legal financial obligations incurred through the criminal system

11. Illinois House Bill 4594, "Criminal and Traffic Assessment Act," 100th General Assembly (2018), https:// www.ilga.gov/legislation/BillStatus.asp?DocNum=4594\&GAID=14\&DocTypeID=HB\&SessionID=91\&GA=100 (accessed August 12, 2021). 
over those of the family, children are unduly punished.

\section{Make De-Identified Data Publicly Available}

Our final recommendation is to make deidentified data about criminal legal involvement and associated monetary sanctions publicly available. Across and within states, there is wide variability in the type, amount, and quality of data about the imposition and collection of monetary sanctions available. Courts and the criminal legal system operate in the public interest. Yet the lack of data availability, and thus the lack of transparency, about what they do and how they do it raises pressing issues of equity and accountability. Inaccessible data shroud the mechanics of a public institution with which millions of people interact daily, reducing our ability to evaluate the system of monetary sanctions, including the inequities it generates, and limiting capacity for effective change. In California, for instance, Mikaela Rabinowitz, Robert Weisberg, and Lauren Pearce report that the data gap is so extensive that these "failings affect researchers' and practitioners' work in criminal justice systems in the state and inhibit critical transparency in the largest criminal justice system in America" $(2019,2) .^{12}$

Among the many structural constraints on data availability is whether the state has an open records policy. The last two columns of table 3, for example, show that almost all of the states in our study have an open records policy; however, in practice, these open record policies do not ensure access to gold standard data, namely administrative court data on monetary sanctions that contain detailed sentencing information including financial amounts separated by fine, fee, surcharge, interest, payment penalties, and payment amounts along with defendant characteristics, case characteristics, and court characteristics. Only Minnesota and Washington-states with comparatively small populations and low incarceration rates-provide data that contain this level of detailed information about monetary sanctions. Other states' data include varying levels of information about monetary sanctions. ${ }^{13}$ Californiathe state with the largest correctional population (Maruschak and Minton 2020, 11) and number of court cases (Judicial Council of California 2020) - limits data availability to researchers, the public, and even lawmakers, who must be granted "special data-gathering powers" by the legislature to access data in order to make very basic policy recommendations to the governor and legislature on criminal legal reforms (see Committee on Revision of the Penal Code 2021, 3; for details, see Rabinowitz, Weisberg, and Pearce 2019). ${ }^{14}$

These information and data gaps are exacerbated when data collection and management systems are outsourced to private entities, as in several states in this study. In Georgia, for example, misdemeanor probation is largely

12. Federally collected data also have limitations in their coverage and level of detail on monetary sanctions. In many court data systems, for example, details about monetary sanctions were often secondary to recording the final dispositions and information about prison time or court-ordered program participation (for more detail, see Martin et al. 2018, 478).

13. For example, data in some jurisdictions in Georgia are available one case at a time. The California Judicial Council's Rules of Court prohibit the bulk distribution of automated, electronic court data. The current data infrastructure is inadequate, and the procedures for requesting access to case and inmate data can be opaque or prohibitive (Rabinowitz, Weisberg, and Pearce 2019). In New York, two entities collect and maintain criminal justice data: the Office of Court Administration and the Division of Criminal Justice Services. Each purportedly keeps monetary sanction data, but neither is able to provide comprehensive, reliable data.

14. California's criminal justice data are compartmentalized across three agencies that shield access: the California Department of Justice, which has data on arrest records and offense disposition from the courts; the Judicial Council of California, which has detailed court data on case processing and adjudication for all fifty-eight counties, including fines and fees; and the California Department of Corrections and Rehabilitation, which has data on inmates in custody and their reentry process, including supervisory costs and the terms of their probation or parole (on probation costs, see Huebner and Shannon 2022, this volume). Each of these agencies has different rules and regulations that limit open access to researchers, practitioners, and the public. 
performed by twenty-four private companies, each of which maintains its own data collection system (Huebner and Shannon 2022, this volume). Similarly, Texas has at least four private companies that provide data management systems and staff often have limited capacity to fulfill any request for data outside legislative mandates (Harris et al. 2017).

Access to high-quality data is essential to making informed decisions about the effectiveness of and inequalities generated by monetary sanctions. For example, evaluations of who can pay, and what amounts, depend on detailed and publicly available records of each case that is heard and adjudicated before a judge. In the absence of these data, researchers and policymakers do not have enough information to create and evaluate different scenarios for payment plans tailored to people of varying economic means. We thus argue that all states should make available de-identified, individuallevel case data, including demographic information about defendants, charges, monetary and nonmonetary sanctions, and detailed amounts of fines and fees sentenced, paid, and outstanding.

\section{CONCLUSION}

What is wrong with monetary sanctions? The system of monetary sanctions is a vast and piecemeal system of laws, policies, and practices that monetize access to just outcomes and undermine equality before the law. People are assessed fines, fees, and other costs on conviction in some states and at the time of a citation in others. Viewed as punishment for wrongdoing, a source of revenue (Pacewicz and Robinson 2020), and an opportunity to demonstrate personal responsibility and accountability (Harris 2016, 137), monetary sanctions have a wide range of supporters and stakeholders. At the same time, they have faced an increasing amount of scrutiny and have been characterized as contributing to a "two-tiered system of justice" (Harris 2016). People who can afford to pay their legal debts can absolve themselves of criminal wrongdoing, whereas those who cannot suffer additional penalties, extended legal involvements, and dehumanization. Problems in the design of monetary sanctions are aggravated by problems of practice at every stage of the criminal legal system.

Ostensibly, fines could function as an efficient and low-cost form of punishment relative to incarceration. Similarly, fees have the potential to generate revenue to offset the costs of the criminal legal system. A subset of those convicted of a criminal offense have the means to pay what they owe. In our observations, however, monetary sanctions inflict disproportionate harm and prolonged entanglement on those least able to do so. Some minimal or superficial benefit of monetary sanctions aside, on the whole, our findings reveal far more harm than good for those of limited means.

Our recommendations are aimed at reducing the scope of monetary sanctions, equalizing access to justice, and ensuring equality under the law. However, the system continues to fall short and have disproportionate impacts. Just one example is that existing law prohibits jailing someone solely on the basis of inability to pay legal debt, and ability-to-pay hearings are a key feature of the system of monetary sanctions in all of the states in our study (see Bearden v. Georgia).$^{15}$ Nonetheless, our observational and interview data show that people are routinely jailed as a consequence of their inability to resolve outstanding legal debt. Many of those jail stays are triggered by capias pro fine warrants issued when defendants fail to appear for a status hearing regarding unpaid fines and fees or for failure to report to a probation officer out of fear of inability to pay (Shannon 2020). Absent a formal ability-to-pay hearing, or determination of willful nonpayment, such incapacitations are likely unconstitutional (Hecht 2017). Thus, although it is essential to revisit the mandate that courts consistently assess ability to pay before making any determinations of willful nonpayment or levying additional sanctions, such gross disregard for the legal intent of Bearden and subsequent legal decisions suggests that more careful consideration needs to be given to how to address the problems related to monetary sanctions.

Drawing on recent work on courts and abo- 
litionist principles (Clair and Woog 2022), we conclude by suggesting that any reforms to the system of monetary sanctions should seek to shift material power from the criminal legal system toward affected populations, to reduce harm caused, and to reimagine ways to account for crimes outside the criminal legal system. Many people who have been assessed legal debt expressed the desire to have their monetary sanctions based on their ability to pay and suggested future policy should permit judges to inquire about an individual's ability to pay before sentencing fines and fees. Study participants said they wanted to pay their monetary sanctions but were often simply unable to manage them. A participant in Illinois described it this way: "It depends on what was more important at the time-if I needed to keep the lights on or if I believed it was to pay the fine. I don't want to go to jail; that scares me."

It was therefore not surprising that when asked for suggestions for reforms, study participants suggested that reforms introduce greater flexibility in payment options and related accommodations. Study participants suggested offering the option of delaying payments for a period of time after incarceration in order to gain their footing, for the provision of legal support, and for help with underlying substance use and mental health issues that inhib- ited their ability to secure employment or hold down a steady job. In our interviews, more than one person who owed legal debt asked simply that they be treated with respect. A participant who owed fines and fees in Georgia put it this way: "I went in there trying to do right, pay these people.... I don't see why somebody will belittle you."

Existing laws, policies, and practices governing monetary sanctions create and perpetuate long-term unequal outcomes particularly for economically marginalized and racialized communities. Conceptualizing our recommendations in relation to how they restore equity, address harm, and empower economically marginalized and racialized communities could guide the development of additional legal templates. Such interventions and recommendations, given that they allow policymakers to identify key stakeholders and carefully recognize the trade-offs associated with immediate and incremental changes to the criminal legal system, can help further advance access to justice and equality before the law. However, questions still remain whether a system based on monetary sanctions can ever be just in a society with so much racial and economic inequality. These questions force us to continue to theorize a legal system that abolishes fiscal penalties.

Table A1. Revenue Generated by Fines and Forfeits, State Plus Local Government Revenues 2013

\begin{tabular}{lccc}
\hline & $\begin{array}{c}\text { Total Fines and Forfeits } \\
\text { Revenue (in Thousands) }\end{array}$ & $\begin{array}{c}\text { Fines and Forfeits } \\
\text { Revenue Per Capita }\end{array}$ & $\begin{array}{c}\text { Fines and Forfeits as } \\
\text { Percentage of } \\
\text { Own-Source Revenue }\end{array}$ \\
\hline California & $\$ 2,605,676$ & $\$ 67.98$ & 0.89 \\
Georgia & $\$ 578,236$ & $\$ 57.87$ & 1.17 \\
Illinois & $\$ 773,943$ & $\$ 60.08$ & 0.86 \\
Minnesota & $\$ 110,629$ & $\$ 20.41$ & 0.27 \\
Missouri & $\$ 230,089$ & $\$ 38.07$ & 0.72 \\
New York & $\$ 2,158,268$ & $\$ 109.83$ & 1.05 \\
Texas & $\$ 1,596,861$ & $\$ 60.38$ & 1.06 \\
Washington & $\$ 294,056$ & $\$ 42.18$ & 0.62 \\
\hline
\end{tabular}

Source: Authors' tabulation based on Census Bureau 2013. 


\section{REFERENCES}

Baumgartner, Frank R., Derek A. Epp, and Kelsey Shoub. 2018. Suspect Citizens: What 20 Million Traffic Stops Tell Us About Policing and Race. Cambridge: Cambridge University Press.

Beckett, Katherine, and Naomi Murakawa. 2012. “Mapping the Shadow Carceral State: Toward an Institutionally Capacious Approach to Punishment." Theoretical Criminology 16(2): 221-44.

Bing, Lindsay, Becky Pettit, and Ilya Slavinski. 2022. “Incomparable Punishments: How Economic Inequality Contributes to the Disparate Impact of Legal Fines and Fees." RSF: The Russell Sage Foundation Journal of the Social Sciences 8(2): 118-36. DOI: https://doi.org/10.7758/RSF.2022 8.2.06.

Boches, Daniel J., Brittany T. Martin, Andrea Giuffre, Amairini Sanchez, Aubrianne L. Sutherland, and Sarah K.S. Shannon. 2022. "Monetary Sanctions and Symbiotic Harms." RSF: The Russell Sage Foundation Journal of the Social Sciences 8(2): 98-115. DOI: https://doi.org/10.7758/RSF.2022 8.2.05.

Brett, Sharon. 2020. "Reforming Monetary Sanctions, Reducing Police Violence." UCLA Criminal Justice Law Review 4(1): 17-48.

Carson, E. Ann. 2020. Prisoners in 2019. Washington, DC: Bureau of Justice Statistics. NCJ 255115.

Clair, Matthew, and Amanda Woog. 2022. “Courts and the Abolition Movement." California Law Review 110(1).

Colgan, Beth. 2019. "Wealth-Based Penal Disenfranchisement." Vanderbilt Law Review 72(1): 55-189.

Committee on Revision of the Penal Code. 2021. Annual Report and Recommendations. Davis: California Law Revision Commission. Accessed August 12, 2021. http://www.clrc.ca.gov/CRPC/Pub /Reports/CRPC_AR2020.pdf.

Demleitner, Nora. 2005. “Smart Public Policy: Imprisonment with Targeted Nonprison Sentences and Collateral Sanctions." Stanford Law Review 58(1): 339-60.

Federal Reserve. 2020. "Report on the Economic Well-Being of U.S. Households in 2019, Featuring Supplemental Data from April 2020." Washington, DC: Federal Reserve Board. Accessed August 12, 2021. https://www.federalreserve.gov /publications/files/2019-report-economic-well -being-us-households-202005.pdf.

Ferguson Commission. 2015. Forward through Fer- guson: A Path Toward Racial Equity. St. Louis, Mo.: Ferguson Commission. Accessed August 10, 2021. https://forwardthroughferguson.org/report /executive-summary.

Fernandes, April D., Brittany Friedman, and Gabriela Kirk. 2022. "The 'Damaged' State vs. the 'Willful' Nonpayer: Pay-to-Stay and the Social Construction of Damage, Harm, and Moral Responsibility in a Rent-Seeking Society." RSF: The Russell Sage Foundation Journal of the Social Sciences 8(1): 82-105. DOI: https://doi.org/10.7758/RSF .2022.8.1.04.

Friedman, Brittany, and Mary Pattillo. 2019. “Statutory Inequality: The Logics of Monetary Sanctions in State Law." RSF: The Russell Sage Foundation Journal of the Social Sciences 5(1): 173-96. DOI: https://doi.org/10.7758/RSF.2019.5.1.08. Greene, Judith. 1988. "Structuring Criminal Fines: Making an 'Intermediate Penalty' More Useful and Equitable." Justice System Journal 13(1): 37-50. Hammons, Brianna. 2021. "Tip of the Iceberg: How Much Criminal Justice Debt Does the U.S. Really Have?" New York: Fines and Fees Justice Center. Accessed August 12, 2021. https://finesand feesjusticecenter.org/content/uploads/2021/04 /Tip-of-the-Iceberg_Criminal_Justice_Debt BH1.pdf.

Harris, Alexes. 2016. A Pound of Flesh: Monetary Sanctions as Punishment for the Poor. New York: Russell Sage Foundation.

Harris, Alexes, Heather Evans, and Katherine Beckett. 2010. “Drawing Blood from Stones: Legal Debt and Social Inequality in the Contemporary United States." American Journal of Sociology 115(6): 1753-99.

—_. 2011. "Courtesy Stigma and Monetary Sanctions: Toward a Socio-Cultural Theory of Punishment." American Sociological Review 76(2): 1-31.

Harris, Alexes, Beth M. Huebner, Karin D. Martin, Mary Pattillo, Becky Pettit, Sarah K.S. Shannon, Bryan L. Sykes, Christopher Uggen, and April D. Fernandes. 2017. Monetary Sanctions in the Criminal Justice System: A Review of Law and Policy in California, Georgia, Illinois, Minnesota, Missouri, New York, North Carolina, Texas, and Washington. A Report to the Laura and John Arnold Foundation. Dallas, Tex.: Arnold Ventures. Accessed August 12, 2021. http://www .monetarysanctions.org/wp-content/uploads /2017/04/MonetarySanctions-Legal-Review -Final.pdf. 
Harris, Alexes, and Tyler Smith. 2022. “Monetary Sanctions as Chronic and Acute Health Stressors: The Emotional Strain of People Who Owe Court Fines and Fees." RSF: The Russell Sage Foundation Journal of the Social Sciences 8(2): 36-56. DOI: https://doi.org/10.7758/RSF.2022 8.2.02.

Harris, Alexes, Mary Pattillo, and Bryan L. Sykes. 2022. "Studying the System of Monetary Sanctions." RSF: The Russell Sage Foundation Journal of the Social Sciences 8(1): 1-33. DOI: https://doi. org/10.7758/RSF.2022.8.1.01.

Harris, Alexes, Tyler Smith, and Emmi Obara. 2019. "Justice 'Cost Points': Examination of Privatization Within Public Systems of Justice." Criminology and Public Policy 18(2): 343-59.

Hecht, Nathan. 2017. "State of the Judiciary." Address to the State Legislature. Austin, Tex.: Texas Judicial Branch. Accessed August 12, 2021. https://www.txcourts.gov/supreme/news/chief -justice-hechts-2017-state-of-the-judiciary.

Huebner, Beth M., and Andrea Giuffre. 2022. "Reinforcing the Web of Municipal Courts: Evidence and Implications Post-Ferguson." RSF: The Russell Sage Foundation Journal of the Social Sciences 8(1): 108-27. DOI: https://doi.org/10.7758 /RSF.2022.8.1.05.

Huebner, Beth M., and Sarah K.S. Shannon. 2022. "Private Probation Costs, Compliance, and the Proportionality of Punishment: Evidence from Georgia and Missouri." RSF: The Russell Sage Foundation Journal of the Social Sciences 8(1): 179-99. DOI: https://doi.org/10.7758/RSF.2022 8.1.08.

Judicial Council of California. 2020. “California Judicial Branch: Fact Sheet." San Francisco: Judicial Council of California. Accessed August 12, 2021. https://www.courts.ca.gov/documents/California _Judicial_Branch.pdf.

Kaeble, Danielle, Lauren Glaze, Anastasios Tsoutis, and Todd Minton. 2016. "Correctional Populations in the United States, 2014." NCJ 249513. Washington: Bureau of Justice Statistics.

Kohler-Hausmann, Issa. 2018. Misdemeanorland: Criminal Courts and Social Control in an Age of Broken Windows Policing. Princeton: Princeton University Press.

Langton, Lynn and Matthew Durose. 2013. "Police Behavior During Traffic and Street Stops, 2011." Washington: U.S. Department of Justice, Office of Justice Programs, Bureau of Justice Statistics. NCJ242937.

Martin, Karin D. 2018. “Monetary Myopia: An Examination of Institutional Response to Revenue from Monetary Sanctions for Misdemeanors." Criminal Justice Policy Review 29(6-7): 630-62.

Martin, Karin D., Kimberly Spencer-Suarez, and Gabriela Kirk. 2022. “Pay or Display: Monetary Sanctions and the Performance of Accountability and Procedural Integrity in New York and Illinois Courts." RSF: The Russell Sage Foundation Journal of the Social Sciences 8(1): 128-47. DOI: https://doi.org/10.7758/RSF.2022.8.1.06.

Martin, Karin D., Bryan L. Sykes, Sarah K.S. Shannon, Frank Edwards, and Alexes Harris. 2018. “Monetary Sanctions: Legal Financial Obligations in the Criminal Justice System." Annual Review of Criminology 1(1): 471-91.

Maruschak, Lauren M., and Todd Minton. 2020. "Correctional Populations in the United States, 2017-2018." NCJ 252157. Washington, DC: Bureau of Justice Statistics. Accessed August 12, 2021. https://www.bjs.gov/content/pub/pdf /cpus1718.pdf.

Mayson, Sandra, and Megan Stevenson. 2020. “Misdemeanors by the Numbers." Boston College Law Review 61(3): 971-1044.

Menendez, Matthew, Michael Crowley, LaurenBrooke Eisen, and Noah Atchison. 2019. “The Steep Costs of Criminal Justice Fees and Fines." New York: Brennan Center for Justice. Accessed August 12, 2021. https://www.brennancenter.org /sites/default/files/2020-07/2019_10_Fees $\% 26$ Fines_Final.pdf.

Miethe, Terrance D., and Charles A. Moore. 1985. "Socioeconomic Disparities Under Determinate Sentencing Systems: A comparison of Preguideline and Postguideline Practices in Minnesota." Criminology 23(2): 337-63.

Miller, Lisa L. 2008. The Perils of Federalism: Race, Poverty, and the Politics of Crime Control. New York: Oxford University Press.

Morris, Norval, and Michael Tonry. 1991. Between Prison and Probation: Intermediate Punishments in a Rational Sentencing System. New York: Oxford University Press.

Natapoff, Alexandra. 2018. Punishment Without Crime: How Our Massive Misdemeanor System Traps the Innocent and Makes America More Unequal. New York: Basic Books. 
Needham, Taylor, Abena Sabira Mackall, and Becky Pettit. 2020. “Making Sense of Misdemeanors: Fine Only Offenses in Convivial Courtrooms." Sociological Perspectives 63(6): 962-77. https:// doi.org/10.1177/0731121420970588.

Pacewicz, Josh, and John Robinson. 2020. “Pocketbook Policing: How Race Shapes Municipal Reliance on Punitive Fines and Fees in the Chicago Suburbs." Socio-Economic Review mwaa029. Accessed August 12, 2021. https://doi.org/10.1093 /ser/mwaa029.

Pattillo, Mary, Erica Banks, Brian Sargent, and Daniel J. Boches. 2022. “Monetary Sanctions and Housing Instability." RSF: The Russell Sage Foundation Journal of the Social Sciences 8(2): 57-75. DOI: https://doi.org/10.7758/RSF.2022.8.2.03.

Pattillo, Mary, and Gabriela Kirk. 2021. “Layaway Freedom: Coercive Financialization in the Criminal Legal System." American Journal of Sociology 126(4): 1-41.

Petersilia, Joan. 1999. "A Decade of Experimenting with Intermediate Sanctions: What Have We Learned?" Justice Research and Policy: Journal of the Justice Research and Statistics Association 1(1): 9-23.

Rabinowitz, Mikaela, Robert Weisberg, and Lauren McQueen Pearce. 2019. “The California Criminal Justice Data Gap." Stanford, Calif.: Stanford Criminal Justice Center. Accessed August 12, 2021. https://www-cdn.law.stanford.edu/wp -content/uploads/2019/04/SCJC-Datagap Report_v07.pdf.

Ruhland, Ebony, Bryan Holmes, and Amber Petkus. 2020. "The Role of Fines and Fees on Probation Outcomes." Criminal Justice and Behavior 47(10): 1244-63. https://doi.org/10.1177/00938548 20918877.

Sances, Michael, and Hye Young You. 2017. "Who Pays for Government? Descriptive Representation and Exploitative Revenue Sources." Journal of Politics 79(3): 1090-94.

Sanchez, Amairini, Michele Cadigan, Dayo AbelsSullivan, Sam Sueoka, Peyton Jacobson, and Bryan L. Sykes. 2022. “Punishing Immigrants: The Consequences of Monetary Sanctions in the Crimmigration System." RSF: The Russell Sage Foundation Journal of the Social Sciences 8(2): 76-97. DOI: https://doi.org/10.7758/RSF.2022 8.2.04.

Shannon, Sarah. 2020. “Probation and Monetary
Sanctions in Georgia: Evidence from a MultiMethod Study." Georgia Law Review 54(4): 121333.

Shannon, Sarah K.S., Beth M. Huebner, Alexes Harris, Karin D. Martin, Mary Pattillo, Becky Pettit, Bryan L. Sykes, and Christopher Uggen. 2020. "The Broad Scope and Variation of Monetary Sanctions: Evidence From Eight States." UCLA Criminal Justice Law Review 4(1): 269-81.

Shannon, Sarah K.S., Christopher Uggen, Jason Schnittker, Melissa Thompson, Sara Wakefield, and Michael Massoglia. 2017. "The Growth, Scope, and Spatial Distribution of People with Felony Records in the United States, 1948-2010." Demography 54(5): 1795-818.

Statutory Court Fee Task Force. 2016. “Illinois Court Assessments: Findings and Recommendations for Addressing Barriers to Access to Justice and Additional Issues Associated with Fees and Other Court Costs in Civil, Criminal, and Traffic Proceedings." Springfield: State of Illinois Supreme Court. Accessed August 12, 2021. https:// www.ilga.gov/reports/special/statutory\%20court \%20fee\%20task\%20force\%20report.pdf.

Stewart, Robert, Brieanna Watters, Veronica Horowitz, Ryan P. Larson, Brian Sargent, and Christopher Uggen. 2022. "Native Americans and Monetary Sanctions." RSF: The Russell Sage Foundation Journal of the Social Sciences 8(2): 137-56. DOI: https://doi.org/10.7758/RSF .2022.8.2.07.

Stuart, Forrest. 2016. Down, out, and under Arrest: Policing and Everyday Life in Skid Row. Chicago: University of Chicago Press.

Sykes, Bryan L., Meghan Ballard, Andrea Giuffre, Rebecca Goodsell, Daniela Kaiser, Vicente Celestino Mata, and Justin Sola. 2022. “Robbing Peter to Pay Paul: Public Assistance, Monetary Sanctions, and Financial Double-Dealing in America." RSF: The Russell Sage Foundation Journal of the Social Sciences 8(1): 148-78. DOI: https://doi.org /10.7758/RSF.2022.8.1.07.

Tonry, Michael, and Mary Lynch. 1996. "Intermediate Sanctions." In Crime and Justice: Review of Research, vol. 20. Washington: U.S. Department of Justice. Accessed August 12, 2021. https://www .ojp.gov/ncjrs/virtual-library/abstracts/crime-and -justice-review-research-volume-20.

U.S. Census Bureau (Census Bureau). 2013. “Annual Survey of State and Local Government Fi- 
nances." Washington: U.S. Department of Commerce. Accessed August 12, 2021. https://www .census.gov/data/datasets/2013/econ/local /public-use-datasets.html.

U.S. Department of Justice, Civil Rights Division (DOJ). 2015. The Ferguson Report: Department of Justice Investigation of the Ferguson Police Department. New York: The New Press.

U.S. Government Accountability Office (GAO). 2018.
“Federal Criminal Restitution: Most Debt Is Outstanding and Oversight of Collections Could Be Improved." A Report to Congressional Committees, GAO-18-203. Washington: Government Printing Office. Accessed August 12, 2021. https://www.gao.gov/assets/690/689830.pdf. Wacquant, Loïc. 2009. Prisons of Poverty. Contradiction Series, vol. 23. Minneapolis: University of Minnesota Press. 